OLENA NAUMKINA,

Sumy State Pedagogical University named after A.S. Makarenko (Sumy, Ukraine)

e-mail: Olena123@gmx.com,ORCID 0000-0002-8136-5663

\title{
COVID-19 PANDEMIC: DIRECTED OR NATURAL FLUCTUATION THAT CHANGES THE WORLD
}

The article presents a synergetic interpretation of the nature, mechanism, and role of the Covid-19 pandemic as a fluctuation that has undergone nucleation in the global system. The choice of methodological bases of our research is due to the fact that synergetics is considered today one of the new promising ways to understand the processes taking place in society, in social systems at the turning points of their development. We assume that this Covid-19 pandemic became the critical fluctuation that quickly spread throughout the world. Today, the global system is in a state of imbalance, in which old connections and structures have been destroyed or are being destroyed, and new ones have not yet been formed. As a result, it fell into the bifurcation zone, where further development becomes unpredictable. The modern world is facing another challenge of history. Therefore, today it is extremely important to determine the range of possible attractors of further evolution of the global system and, at the same time, those that are achievable and favorable to humanity. From a philosophical point of view, we can talk about being that appears before our eyes, about the birth of a new reality in which we have to live. It was found that the synergetic methodology involves the creation (consciously) of the necessary conditions for the introduction into the system of the desired fluctuation with signs of a new desired quality, and promote its nucleation. This will lead to the formation of new organizational integrity and the transition to a new evolutionary channel of development. That is why today, various conspiracy theories about the origin of the Covid-19 pandemic are actively spreading. The attitude to them is ambiguous. However, several facts force us to analyze them and draw appropriate conclusions carefully. It is noted that the lack of reliable information does not yet allow us to give an unambiguous answer about the nature of this fluctuation. However, there is no doubt that it has become a powerful factor in forming a new reality, a bifurcation transition to a new - and, so far, not clearly defined - attractor of the evolution of the global system.

Key word: Attractor; Bifurcation; Nucleation; Covid-19 pandemic; Synergetics; Fluctuation.

\section{Introduction}

It seems that at last the time for philosophy has come. Nowadays one observes the huge social demand for philosophical reflection of the crisis the world faces these days. Moreover, to a greater extent, the society requires the answer to the question on the future of the global system. As Levitskiy rightly notes, "pandemic and measures for preventing the virus that caused it are so unprecedented in the new history that put the question not only for epidemiologists, virologists, and economists but also require the philosophical reflection" (Levitskiy, 2020).

The Covid-19 pandemic made the global world crisis more visible, the one that directly everyone feels today. Today Homo Sapiens is afraid of chaos, uncertainty, confusion related to both the existential aspects of the human existence and the rapid change of social practices. Psychodemia, which covered the planetary community, showed that even ordinary citizens felt the "breath" of a new incomprehensible, fuzzy future. And if at the beginning of strict restrictive measures around the world, our existence was accompanied by psychoemotional unrest, now more and more people are trying to use rational mechanisms to understand what is happening, and

ISSN 1728-9343 (Print)

ISSN 2411-3093 (Online) what future awaits us, what are the contours of the world to which humanity has to adapt itself.

Many thinkers, social theorists, futurologists predicted this world crisis in advance. They tried to warn humanity about the new risks, negative consequences of those social practices, standards, ethical and axiological instructions that became widespread, especially at the beginning of the 21st century. And only now these warnings, the implementation of these forecasts are of interest and concern not only for the world political elites but also the general public. The Covid-19 pandemic has triggered the full deployment of the crisis. Hence, there has been an urgent need for a philosophical understanding of its nature and role to find optimal ways out of the global crisis situation, preferably with the least possible destructive consequences.

How can philosophy help us understand what is happening to us today and, in general, in the crisis moments of human existence? First of all, as G. Lourdes Velazquez notes, "the philosopher's task is not to find the meaning of life or tell others how they should live, but to provide conceptual tools useful to those who make difficult decisions, communicating and explaining them to others. If we see philosophy in this way, there is still much work for philos- 
ophers, not only in the current situation, but perhaps, first of all, in the future" (Lourdes Velázquez, 2020).

The theoretical foundations of our research are based on the fundamental works of philosophers, sociologists, futurologists regarding the attributes of modern civilization and the projects of its future. Among them there is a wave concept of development of society of E. Toffler, concept of "society of risk" of the German sociologist U. Beck, society of "late modernity" of E. Giddens. We also relied on ideas regarding the post-human future of F. Fukuya$\mathrm{ma}$, reflections on the era of spiritualized machines and forecasts of the future of R. Kurzweil, an essay by B. Joey on the creation of artificial intelligence systems, the rapid development of genetic engineering, nanotechnologies that provoke completely new types of disasters, the concept of universal evolutionism of M. Moiseev (scenario of information totalitarianism), the work of $\mathrm{P}$. Tyshchenko, $\mathrm{V}$ Cheshko, $\mathrm{V}$ Hlazko on the role of bio-power in the era of biotechnology in a risk society.

Of interest for our study were the works "A Brief History of Tomorrow" and "21 Lessons for the 21st Century" by the Israeli philosopher and historian Yu. N. Harari, a discussion of the famous modern European philosophers Giorgio Agamben (Agamben, 2020) and Jean-Luc Nancy regarding the Covid-19 pandemic and its impact on the formation of a new reality. We also relied on biology studies to model a modern pandemic based on a synergistic approach (Frank, 2020).

The paper aims to synergistically interpret the nature, mechanism and role of the pandemic Covid-19 as a fluctuation that has undergone nucleation in the global system and has become a powerful factor in the formation of a new reality.

\section{Methods of the research}

The choice of methodological foundations of our research is because synergy is considered today one of the new promising ways to understand the processes taking place in complex systems of a diverse nature, including social ones, at turning points, crisis moments of their development and constituting the "scientific basis of modern management theory" ( $A$. Kniaziev). The work used a synergistic methodology since the subject of its study is precisely the processes of self-organization of complex systems in conditions of imbalance. We relied on the key ideas and principles of synergy that were developed by its funders (I. Pryhozhyn, I. Stengers, G. Haken), and then were developed in the works of $\mathrm{V}$. Arshinov, K. Delokarov, A. Kniazieva, S. Kudriumov, V. Lectorskyi, V. Stiopin and others. Many constructive ideas on the use of synergies in the processes of modeling the development and management of complex systems are presented in the studies of Ukrainian specialists (L. Bevzenko, L. Horbunov, I. Dobronravova, V. Lukianets), as well as famous foreign ones (V. Branskyi, V. Budanov, A. Kniazieva, L. Kiyashchenko, S. Kurdiumov, H. Malinetskyi, A. Ursul).

In our study, we relied on a synergistic methodology for understanding and managing complex systems. Among the key principles were applied the following: openness, nonlinearity, cooperativity and coherence, chaos as a constructive beginning of the self-organization of complex systems and the like. The principle of harmonizing the self-organizational mechanisms of the evolution of social systems and their management (organization) became especially important: how to find a balance between these two principles, how to direct the development of the system to the evolutionary attractor desired for the subject.

\section{Results and Discussion}

We assume that the Covid-19 pandemic has become the critical fluctuation that "pushed" the global system to the bifurcation zone. Today, the world is in a state of imbalance, in which old ties have been destroyed or are being destroyed, the structure, and new ones have not yet formed. From a philosophical point of view, we can talk about the emerging existence of the birth of a new order, about the mechanisms of its formation. Slovenian writer-philosopher S. Žižek, who is known for his provocations, has already written a book with the symptomatic title "Pandemic!: Covid-19 shakes the world." Of course, one can disagree with him in many things, but it is undeniable that the transformations that this crisis will entail will force us to consider the world "before" and "after." The famous Israeli philosopher Yu. N. Harari notes that "choosing between alternatives, we should ask ourselves not only how to overcome the immediate threat but also what kind of world we will settle when the storm passes. Yes, the storm will pass, humanity will survive, most of us will still be alive - but we will settle in another world" (Harari, 2020). Already during the year, we observe in the list of discussed problems of many conferences, the vocabulary of philosophers, experts in various fields new phrases: "world before and after Covid-19," "post-Covid world," etc.

Let us try to figure out what is happening to the world as a self-organizing super-complex social system. At the same time, let us not forget that this system is human, which complicates the process of its knowledge and, accordingly, its management.

From a synergistic point of view, the process of selforganization in general terms can be represented as follows: self-organization begins only in an open system that exchanges energy, substance and information with the environment; as the flow of energy, substance, information increases, the system becomes unbalanced, which leads to the instability of its old structure; this causes interoperability and interconnection of system elements; fluctuations occurring in an unbalanced system gradually increase and contribute to the "loosening" of its stability; when one of many fluctuations reaches critical values, it experiences nucleation (rapidly spreads and covers the entire system); if such nucleation has taken place, the system as a whole reaches the point of bifurcation (branching); in the system, cooperative and coherent behavior of elements that moved towards this randomly is observed; correlations arise between the elements of the system, which leads to a new nature of their interaction; according to the "cooperative effect," the old ones are destroyed and new structures of the system appear that qualitatively change its nature.

So, our planetary system belongs to the class of open, which constantly exchange a variety of resources with the environment. This exchange was especially intensified in the context of the globalization of the modern world. From the middle of the 20th century, its pace began to grow rapidly. This was facilitated by STD, and in recent years the rapid development of the complex of NBICS technologies. As a result, various types of fluctuations began to accumulate in the system. First of all, we are talking about the fact that the structure of economic and social reality began to be determined not by real resources and flows, but by information; in the composition of social existence, technical means of adapting a person to the natural environment, as well as regulating their own everyday life, began to gain increasing weight; the growing 
interdependence of different regions of the world has led to the destruction of traditional patterns of social action, values, lifestyles and the like.

Accordingly, the imbalance of the system, the instability of its old structure began to grow. This turned out to be in the activation of the movement of anti-globalists, greens, nationalists, right-wing political forces, and the crisis of liberalism. As Harari rightly points out, the sense of confusion and impending catastrophe is heightened by the increasing pace of technological progress. The liberal political system was formed in the industrial era to control the world of steam engines, oil refineries and televisions. It is difficult for it to adapt to the continuous revolutionary changes associated with the development of biotechnology and information technology (IT) (Harari, 2018).

Among other emerging trends that contribute to the destruction of the old structure of the modern world is protectionism, which has rapidly begun to spread in recent years. The most striking examples in this sense are Trump's neoprotectionism, Brexit (Britain's exit from the EU), which was the result of the dissatisfaction of most citizens of the United Kingdom with the total dictatorship of Brussels and the European bureaucracy, especially regarding economic and migration policies.

Let us not forget the consequences of the 2008 global financial crisis. Rolf Langhammer, former director of the German Institute for World Economy, explains these trends by saying that global economic growth has slowed in recent years. This exacerbated the distributive conflicts for which the right-wing populists place responsibility for globalization. At the same time, the root of evil lies more in technical progress. Automation processes in manufacturing in many areas reduce the need for personnel. Enterprises lay off workers, reducing production costs (Tramp i strakh globalizatsii, 2016). Everybody heard about the destructive results of innovative activity, which exacerbated not only social, but also security problems, environmental problems.

Thus, these and other impacts have disrupted the interaction and interconnection of elements of the global system. Fluctuations gradually intensified and contributed to the "loosening" of its stability, the growth of its entropy. And, as synergy postulates, in a state, the system is extremely sensitive to external influences. Little fluctuation is enough to produce macroscopic consequences in a complex system. In our opinion, the Covid-19 pandemic became the fluctuation (the so-called "last straw") that reached critical values and caused nucleation (quickly spread and covered the entire system). Recall how, in a matter of weeks, the countries began to close, closing the borders, logistics operations were ceased, a wide range of traditional civil rights and freedoms (movements, meetings) was limited. The world appeared to be in total quarantine, self-isolation.

Since the beginning of the pandemic, the global system has experienced panic, confusion due to a lack of objective information about both the origin of the virus itself, its transmission mechanisms, the degree of contagiosity, the percentage of mortality, the constantly changing protocols for its treatment, and the consequences of leaving quarantine, especially socio-economic ones. And today, at the beginning of 2021, uncertainty in the world is growing. We only have time to get information about the constant mutations of this virus, new strains (for example, British, South American, Brazilian, which again forced countries to close), about hard lockdowns in certain regions of the world. Many pinned their hopes on the emergence of vaccines against Covid-19. But, again, another question and problem arises: how effective and safe they are, given the shortened duration of clinical trials and the number of mutations of this virus, their disproportionate distribution between rich and poor countries. Increasingly, we hear about "vaccine nationalism." Even Pope Francis noted this in his Christmas message.

Under such circumstances, how can we even make short-term forecasts and make effective management decisions at various levels and in all spheres of society? Such uncertainty further enhances the entropy of the global system.

In these circumstances, philosophers focus on understanding the existential problems provoked by the pandemic, the transformation of social practices and values of society, and, in general, the formation of a new reality. In this regard, many thinkers, experts have an interesting and, at the same time, important question regarding the nature of this fluctuation. Synergetics implies the ability of a subject to create the necessary conditions for introducing the desired fluctuation into the system with signs of a new desired quality and to promote its nucleation. So, the problem can be formulated so: is the Covid-19 pandemic accidental fluctuation, manifestation of natural mechanisms of self-organization or the instrument of purposeful management of a global system? Was it provoked, organized by certain actors and designed for the desired result for them?

Based on knowledge of the mechanisms of selforganization, we recall the basic rules for managing complex systems:

- the control entity must determine which future is acceptable and desirable for the system and, at the same time, possible from the spectrum of its attractors;

- constant monitoring of the level of system imbalance;

- creating the necessary conditions for introducing the desired fluctuation with signs of the new desired quality into the system and facilitating its nucleation;

- simultaneous reorientation or oppression of the development of "undesirable" structures that do not correspond to the main direction of evolution of the system;

- maximizing the promotion of the "cooperative effect" by the elements and the co-evolution of the various hierarchical levels of the system, which will lead to the formation of a new organizational integrity and the transition of the system to a new evolutionary channel of development.

It is necessary to take into account that (Kurdyumov, Knyazeva, 2002: 113-123):

- the controlling act must resonate with internal trends in the development of a system that is self-organizing;

- in a non-equilibrium state, non-force interactions play a significant role: small, but consistent with the internal potentials of the system of acts are more effective than significant ones;

- the controlling act must be carried out gradually, step by step, based on fuzzy adaptive control.

Given the above, such an option (conscious introduction of the necessary fluctuation into the system) cannot be discarded theoretically. Therefore, various conspiracy theories regarding the pandemic of Covid-19, its origin and nature are actively spreading today. The attitude towards them is ambiguous. However, several facts compel them to carefully analyze and draw appropriate conclusions.

First of all, let us recall the report of The Rockefeller Foundation and Global Business Network "Scenarios of the Future of Technology and International Development," 
presented in 2010. It talks about four scenarios for the future of the world until 2030: Lock Step, Clever Together,
Hack Attack that Smart Scramble (Scenarios for the Future, 2010: 16)

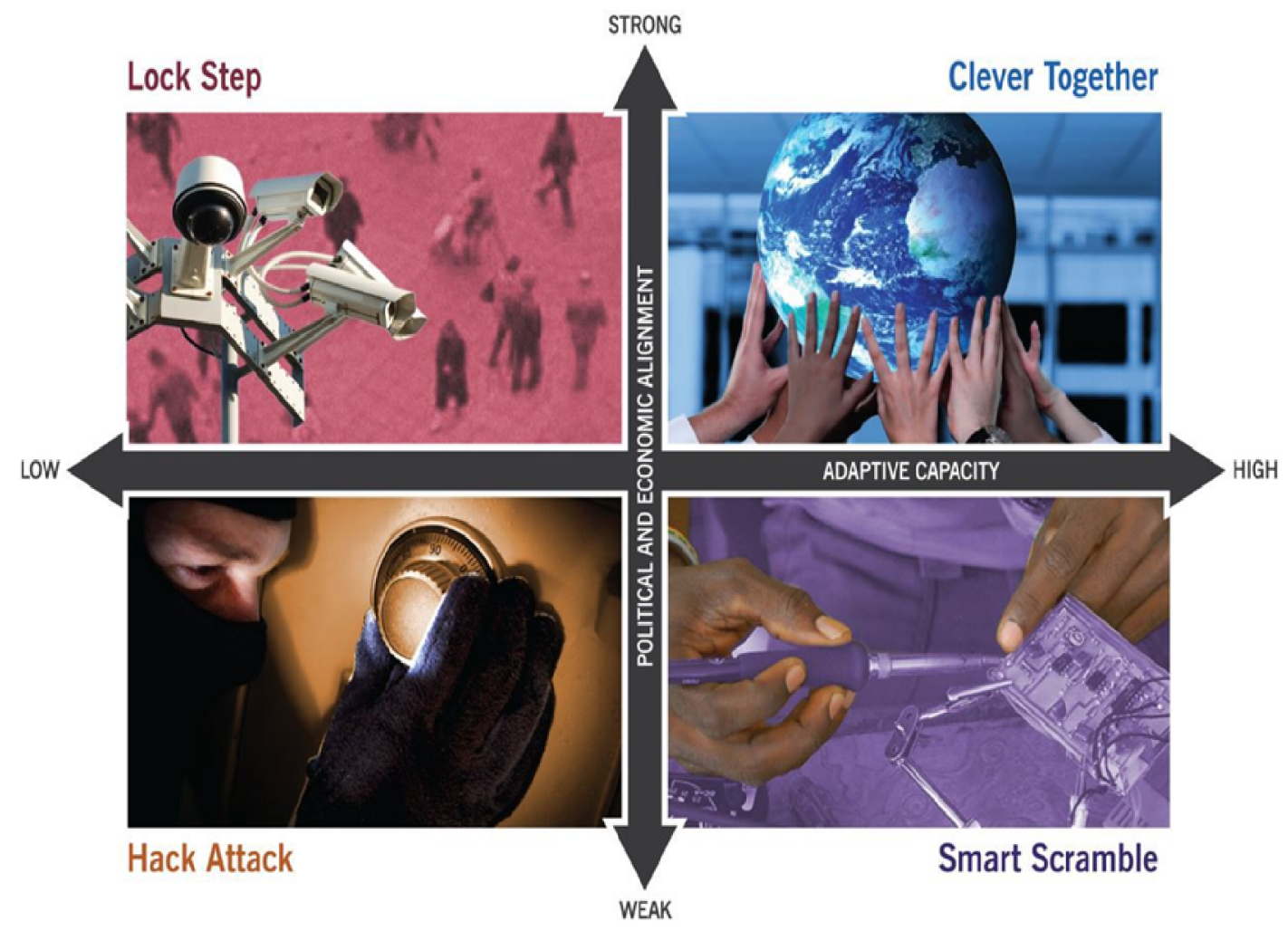

For our research, the first is very interesting. The Lock Step scenario is a split version of the world. It has tight control by governments, authoritarian leadership, limited and controlled innovation and civil rights and freedoms. The event that triggered such a scenario was a global pandemic caused by a new strain of flu from wild geese extremely virulent and deadly. Even the most pandemicready nations could not cope with this. The virus swept the world, almost 20 percent of the population was infected, and 8 million died in just seven months. The pandemic had a great impact on the economy: international mobility of people and goods ceased, tourism was depleted, global supply chains were destroyed. Even locally ordinary fuss in stores and offices stopped... (Scenarios for the Future, 2010: 18). One cannot but admit how exactly the Lock Step scenario corresponds to what we have been seeing in the world for the second year in a row. Was such an accurate forecast made 10 years ago?

There is another known fact. Microsoft founder Bill Gates, since 2010 , has repeatedly warned of the global epidemic of the virus and its threatening consequences. He even called the likely source - China. But, most importantly, the billionaire emphasized the unwillingness of the world to resist this. At the TED conference (technology, entertainment and design), he focused on the need for the world to prepare for the next major health crisis. "NATO plays war games to check that people are welltrained and prepared. Now we need germ games," he said (Wakefield, 2015). Back in 2000, he and his wife became the founders of the Bill \& Melinda Gates Foundation. It is a charity that invests in improving the health system around the world and fighting epidemics. In February 2020 , this fund announced the allocation of $\$ 100$ million to combat the spread of the new virus.
In August 2020, The Rockefeller Foundation and Access Health International presented the report "Digital Health. Tackling COVID-19 Pandemic through Integrating Digital Technology and Public Health: Linking Experiences in China to the World" (Digital Health, 2020). The study analyzes China's experience in the fight against Covid-19, the country that was the first to face this crisis. Key findings presented in the report showed the effectiveness of digital technologies in containing and responding quickly to coronavirus outbreaks in various regions of China. Among the key success factors was the use of digital technologies at both the state and local levels. In particular, it is noted that these technologies were an instrumental part of the government strategy to introduce strict measures to contain the epidemic. A vast technological infrastructure has quickly come into operation, tools have been deployed to access and disseminate information, track people and their contacts, access daily necessities, and more.

The analysis of these and other facts leaves open the question of the nature of the fluctuation associated with the Covid-19 pandemic at least today for lack of reliable information. However, Andrej Baumeister rightly notes that one cannot smile and be ironic about the idea of world conspiracies, "since, of course, there are centers of influence, people or groups who can benefit ... I would like to say about certain interests not at the level of creation of problems, but at the level of use of consequences..." (Polishchuk, 2020). In such a situation, the ability of people becomes extremely important... "distinguish between the real concern for the life of citizens and the strengthening of disciplinary power, which will control both the spiritual and physical life of a person. Let's keep our eyes open" (Dodonova, Dodonov, 2020). 


\section{Conclusions}

So, let us state that the Covid-19 pandemic became the fluctuation ("last straw") that reached critical values and underwent nucleation. As a result, the global system fell into the bifurcation zone. The modern world was faced with another "challenge in history." It should be noted that so far there is a lack of reliable information regarding the nature of this fluctuation, but theoretically it could be deliberately provoked. This issue remains open. But there is no doubt that it has become a powerful factor in the formation of a new reality, a bifurcation transition to a new yet clearly uncorrected - attractor of the global system evolution.

In this context, determining the range of future scenarios that exist in the global system becomes extremely important. Which of them is achievable and at the same time favorable to mankind? What will be the world of the future? What reality is formed before our eyes? Thinkers, scientists, experts are already arguing about this. Among the main predictions about future attractors, the following can most often be found: the end of globalization or neoglobalization, the transition from liberalism to totalitarianism, in particular, information, biopolitical, the dehumanization of social distancing practices, new online forms of business and training, and others. But this is already the subject of further research and discussion by many specialists.

\section{REFERENCES}

Agamben, G. (2020, February 26). L'invenzione di un'epidemia. Quodlibet. https://www.quodlibet.it/giorgio-agamben-I-invenzione-di-un-epidemia

Digital Health (2020, August). Tackling COVID-19 Pandemic through Integrating Digital Technology and Public Health: Linking Experiences in China to the World. The Rockefeller

Олена Наумкіна,

Сумський державний педагогічний університет імені А.С. Макаренка

e-mail: olena123@gmx.com,ORCID0000-0002-8136-5663
Foundation and Access Health International. https://www.rockefellerfoundation.org/wp-content/uploads/2020/09/v7 RF-Final-Report AHI 2020903 reduced.pdf

Dodonova, V. and Dodonov, R. (2020). Transformation of social values during a pandemic and problems of global solidarity. Skhid. 3(167): 21-26. https://doi.org/10.21847/1728-9343.2020.3(167).206757

Frank, T. D. (2020). Covid-19 order parameters and order parameter time constants of Italy and China: a modeling approach based on synergetics. Journal of Biological Systems. 28 (3): 589-608. https://doi.org/10.1142/S0218339020500163

Harari, Yu. N. (2018). 21 urok dlya XXI veka. LoveRead.ec. http://loveread.ec/read_book. php?id=80945\&p=3

Wakefield, Jane (2015, March 19). TED 2015: Bill Gates warns on future disease epidemic. BBC news. https://www.bbc.com/news/technology-31956344

Kurdyumov, S. and Knyazeva, Ye. (2002). Struktury budushchego: sinergetika kak metodologicheskaya osnova futurologii. Sinergeticheskaya paradigma. Nelineynoye myshleniye $v$ nauke $i$ iskusstve. Moscow: ProgressTraditsiya, pp.109-125.

Levitskiy, V. S. (2020, April 27). Filosofiya pandemii. UISGDA. https://uisgda.com/ru/filosofiya-pandemii.html

Lourdes Velázquez, G. (2020, March, 26). The role of philosophy in the pandemic era. Bioethics Update, 6 (2), JulyDecember: 92-100. https://doi:10.1016/j.bioet.2020.08.001

Polishchuk, A. (2020, March 26). Shcho chekaye na nas pislya. Den. 56-57. https://day.kyiv.ua/uk/article/podrobyci/shchochekaye-na-nas-pislya

Scenarios for the Future of Technology and International Development (2010, May). The Rockefeller Foundation and Global Business Network. https://www.nommeraadio.ee/meedia/pdf/RRS/Rockefeller\%20Foundation.pdf

Tramp i strakh globalizatsii (2016, November, 16). Europa.com. https://euroua.com/world/usa/9058-tramp-i-strakh-globalizatsi

Harari, Yuval Noah (2020, March, 20). The world after coronavirus. Financial Times. https://amp.ft.com/content/19d903086858-11ea-a3c9-1fe6fedcca75\#

\section{ПАНДЕМІЯ COVID-19: СПРЯМОВАНА ЧИ ПРИРОДНА ФЛУКТУАЦІЯ, ЯКА ЗМІНЮЕ СВІТ}

У статті здійснена синергетична інтерпретація характеру, механізму і ролі пандемії Covid-19 як фрлуктуації, що зазнала нуклеації в глобальній системі. Вибір методологічних засад дослідження зумовлений тим, що синергетика вважається одним із нових перспективних методологічних підходів для розуміння процесів у складних системах, в тому числі соціальних, у переломні моменти їхнього розвитку, в так званих точках біфуркації. Пандемія Covid-19 стала критичною флуктуацією, яка швидко поширилася по всьому світу, тобто зазнала нуклеації. Внаслідок цього глобальна система потрапила до зони біфуркації. Ії̈ стан характеризується значним порушенням рівноваги, коли старі зв'язки та структури були зруйновані або руйнуються, а нові ще не сформовані. В такому стані система є вкрай неврівноваженою, нестабільною, чутливою до будь-яких впливів, навіть незначних. Потрапляння до зони біфуркації означає, що подальший розвиток нашої глобальної системи стає непередбачуваним. Сучасний світ постав перед черговим «викликом історії». Через те сьогодні надзвичайно важливо окреслити спектр можливих атракторів подальшої еволюції глобальної системи і водночас таких, які є досяжними та сприятливими для людства. 3 філософської точки зору, ми говоримо про буття, що постає на наших очах, про народження нової реальності, до якої ми маємо адаптуватися і в якій будемо жити. 3'ясовано, що синергетична методологія передбачає можливість свідомого введення до системи необхідної флуктуації, щоб вивести її на бажаний атрактор еволюції. Саме тому сьогодні активно поширюються різні теорії змов щодо походження пандемії Covid-19. У статті наведені деякі конспірологічні теорії щодо виникнення сучасної пандемії. Проте, зазначається, що брак достовірної інформації поки-що не дозволяє дати однозначну відповідь щодо характеру цієї флуктуації: чи є вона спрямованою, чи природною. При цьому наголошується, що безсумнівно, вона спровокувала біфуркаційний перехід до нового (поки що чітко неокресленого) атрактора еволюції глобальної системи та стала потужним чинником формування нової реальності.

Ключові слова: атрактор; біфуркація; нуклеація; пандемія Covid-19; синергетика; фрлуктуація.

(c) Olena Naumkina

Надійшла до редакції: 14.12.2020, Прийнята до друку: 29.01.2021 